Corresponding Author:

Madis Saralita

madis.saralita@gmail.com

Received: 7 February 2020

Accepted: 9 March 2020

Published: 23 March 2020

Publishing services provided by

Knowledge E

(c) Madis Saralita and Niken

Ardiyanti. This article is

distributed under the terms of

the Creative Commons

Attribution License, which

permits unrestricted use and

redistribution provided that the

original author and source are

credited.

Selection and Peer-review under

the responsibility of the

ICE-BEES 2019 Conference

Committee.

\section{Role of Workplace Spirituality and Perceived Organizational Support on Turnover Intention: Evidence from Private Hospital in Indonesia}

\section{Madis Saralita ${ }^{1}$ and Niken Ardiyanti ${ }^{2}$}

${ }^{1}$ Magister of Management, Faculty of Economics and Business, Universitas Indonesia - Indonesia

${ }^{2}$ Faculty of Economics and Business, Universitas Indonesia - Indonesia

\section{Abstract}

Nowadays, the success of an organization depends heavily on employees' productivity which can be influenced by employees' health conditions. Generally, either an organization or individual need hospital for health services. This has an impact on the growth of hospitals which continues to increase, so that competition in the health industry will be even higher. Therefore health industry stakeholders require to continue improving their services, either through improved facilities or improvements from the employees' side. Based on research, turnover intention is one of many problems which must be solved by health industry stakeholders. Many factors can influence turnover intention, i.e. workplace spirituality, perceived organizational support, and organizational commitment. The purpose of this study was to know the effects of these factors on turnover intention mediated by organizational commitment. A total of 235 employees from private hospital in Jakarta participated as respondents. Data obtained through questionnaires and then analyzed using SEM. The results showed that organizational commitment was positively influenced by perceived organizational support and workplace spirituality. Furthermore, workplace spirituality and organizational commitment negatively affected turnover intention. Organizational commitment can mediate the relationship between workplace spirituality and turnover intention.

Keywords: turnover intention, workplace spirituality, perceived organizational support, organizational commitment, hospital

\section{Introduction}

According to King, Renó, \& Novo (2014) one of basic needs that is very important for humans is health. It was also mentioned in Kirsten (2010), study of several organizations that adopted occupational health promotion strategies mention that health had direct impact on human productivity. Therefore, humans need to maintain health and obtain health services to keep their productivity. One of places in getting health services is a hospital. This has led to an increase in the number of hospitals, so a new strategy 
is needed in conducting business in the health sector. In addition, in developing this strategy, businesses must look at one of the important factors, namely human resources. Human resources are an important part of developing this strategy because it plays an important role in the company. In addition there is also an increase in the number of hospitals in line with the increase in the number of existing jobs in the health sector which has led to increased motivation of employees who feel less suitable with the hospitals where they currently work to move to other hospitals (Direnzo \& Greenhaus, 2011). Crook, Todd, Combs, Woehr, \& Ketchen (2011) mention that human resource management as a form of investment can provide increased performance to organizations broadly and to employees specifically.

Based on the research of Direnzo \& Greenhaus (2011) the importance of human resources makes hospitals have to be able to keep their employees from moving to other hospitals or have high turnover intention. Therefore, it is also important to know what can affect turnover intention. There are various factors that influence turnover intention, including workplace spirituality (Gatling, Kim, \& Milliman, 2016), perceived organizational support and organizational commitment (Filipova, 2011). In accordance with Filipova (2011), organizational commitment from employees is one of the factors that can influence turnover intention. In line with the research of Gatling, Kim, \& Milliman (2016), workplace spirituality is one of the factors that can influence turnover intention. Spirituality experienced by such employees according to Lee, Lovelace, \& Manz (2014) can influence the quality of services provided by employees to their customers.

Based on the background that has been described, it is expected that conducting research on workplace spirituality can help answer how the strategies carried out can influence organizational commitment and turnover intention. In addition, one other important factor is the perceived organizational support, namely how perceived organizational support are felt by employees so that it can be one of the judgments that underlies the level of organizational commitment and in the end it will also affect the employee's desire to move his work to another workplace. Therefore, this study will modify the Gatling, Kim, \& Milliman (2016) research model and Filipova (2011) who see organizational commitment as a mediator. To further examine the issue of turnover intention, this study will focus on workplace spirituality and perceived organizational supportas independent variables that emerge as influential factors where these variables will influence organizational commitment as a mediator variable and ultimately affect turnover intention. 


\section{Literature Review}

\subsection{Turnover Intention}

According to Takase (2010), turnover intention is stated in other terms such as the intention to quit, intention to leave, and intention to turnover. The term turnover itself refers to employees who leave the company or resign (Dessler, 2013). Turnover intention is referred to as a condition when employees start thinking, have desires and deliberately look for other jobs in the near future (Hee, Yean, \& Ling, 2011). While in the study of Pallas, Murphy, Shamian, Li, \& Hayes (2010) and Kovner et al. (2016) turnover is described as a process where employees leave the organization or move between units within the organization. Vnoučková, Urbancová, \& Smolová (2016) states that employees generally choose to leave their jobs because they consist of several reasons, including tangibles (salary and benefits) and intangible reasons (supervisor support, work-life balance, career path, management trust which is not satisfactory.

\subsection{Workplace Spirituality}

Petchsawang \& Duchon (2012) states that workplace spirituality is to have compassion for others, experience inner awareness in carrying out meaningful work. There are several common dimensions discussed in the conceptualization of workplace spirituality such as fulfilling a very personal inner need in the workplace, a strong sense of togetherness with others in the workplace, and closely related to values in a person (Gatling et al., 2016). Chawla \& Guda (2010) shows spirituality in the workplace can affect job satisfaction (Altaf \& Awan, 2011; Gupta, Kumar, \& Singh, 2014) and organizational commitment (Kazemipour \& Amin, 2012). Employees who experience spirituality in the workplace tend to be able to provide services to consumers as well as possible so that it can affect the quality and quality felt by consumers (Jena \& Pradhan, 2018; Vandenberghe, 2011; Beehner \& Blackwell, 2016).

\subsection{Perceived Organizational Support}

Perceived organizational support reflects the extent to which employees believe that organizations value their contribution and truly care about their welfare (Kinicki \& Fugate, 2016). The research of Kurtessis et al. (2017) defines perceived organizational supportas as to how employee contributions are valued by an organization and how much the organization cares about their welfare. Whereas seen from the reciprocal relationship, 
perceived organizational support will foster the feeling of employees to always care about the welfare of the organization and help the organization in achieving its goals (Kurtessis et al., 2017). Chiaburu, Dam, \& Hutchins (2010) in his theory revealed that employees will have a desire to help organizations achieve their goals if they feel valued. Employees who feel involved will have high performance and commitment.

\subsection{Organizational Commitment}

Organizational commitment is an issue that is a challenge for HR Management in increasing the level of organizational competition (Wong \& Tong, 2014). This organizational commitment is one of the important attitudes for the company, because someone who has a high commitment will strive to help achieve organizational goals and still want to work in the organization (Kreitner \& Kinicki, 2010). In general, organizational commitment is defined as a psychological relationship that is created between employees and organizations so that employees do not have the desire to leave the organization (Brimeyer, Perrucci, \& Wadsworth, 2010). Kehoe \& Wright (2013) also defines organizational commitment as how much employees are involved in their organization.

\section{Methodolgy}

This study aims to see how the mediating role of organizational commitment in the relationship between the spiritual workplace and the perceived organizational support for turnover intention. This study produced seven hypotheses, each of which explained the relationship between research variables described in Figure 1. The hypothesis of this study are as follows:

H1: Workplace spirituality positively affects organizational commitment.

$\mathrm{H} 2$ : Perceived organizational support positively affects organizational commitment.

H3: Organizational commitment negatively affects turnover intention.

$\mathrm{H} 4$ : Workplace spirituality negatively affects turnover intention.

H5: Perceived organizational support negatively affects turnover intention.

H6: Workplace spirituality negatively affects turnover intention mediated by organizational commitment.

H7: Perceived organizational support negatively affects turnover intention mediated by organizational commitment. 


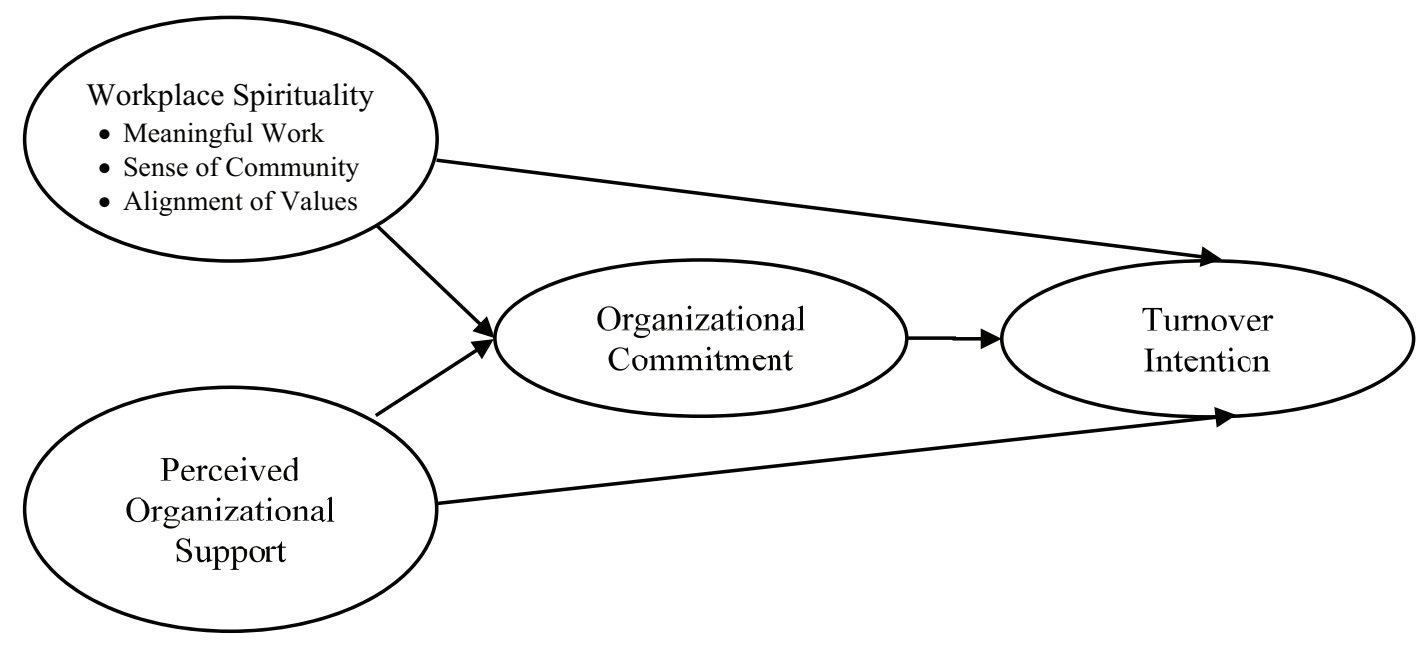

Figure 1: Conceptual model.

The method used in this study is a quantitative method. To analyze the hypothesis, a structural equation modeling (SEM) method is used using the help of the SPSS device Amos and Lisrel 8.7. Sources of data in this study are primary data and secondary data. The questionnaire used for each variable was taken from several previous studies. The 23 items used to measure workplace spirituality came from a study developed by Ashmos \& Duchon (2000). Perceived organizational support are calculated using 6 questionnaire items from a study developed by Eisenberger, R. and Huntington (1986). Furthermore, 15 items of questionnaires to measure organizational commitment came from a study developed by Mowday, Steers, \& Porter (1979). While turnover intention is calculated using 3 questionnaire items from a study developed by Jones (1986) research with the addition of statements from Chung's research. The scale used is adjusted to the questionnaire in the study which is using 6 likert points. The population of this study is all employees at a private hospital in Indonesia. At the pretest stage, the author took a sample of 30 respondents to test the validity and reliability of the questionnaire items. While for the main-test, the author involved 235 hospital employees.

Before conducting SEM analysis, this research will analyze the validity and reliability test. pre-test analysis will see the level of validity and reliability of the questionnaire. Validity will be measured using KaiserMeyer-Olkin (KMO), while reliability will be seen from the Cronbach value. After that a descriptive analysis will be carried out for the respondents' demographics and also the descriptive variables. Then tested the validity using SFL, while for reliability will use the Construct Reliability and Variance Extracted test. To do hypothesis analysis, SEM (Structural Equation Modeling) is used to test the relationship between variables and hypotheses. After pre-testing the questionnaire, the items used in the pre-test will be used in the main test because the results of the items 
for testing validity and reliability testing indicate that all questionnaires are valid with all values above 0.6 for the Cronbach value, and $\mathrm{KMO}$ more from or equal to 0.5 . The results of validity and reliability indicate that there are 6 items that are invalid so they are not included in the main test. Furthermore, reliability testing at the main-test stage uses composite reliability (CR) and variance extracted (VE). Reliability testing is done using Lisrel Software. Evaluation of the reliability of the measurement model can be calculated using the values of CR and VE. The results can be said to be reliable if the CR value is above or equal to 0.70 . Conversely another way to see reliability is through VE with the appropriate standard, which must be greater than or equal to 0.50. VE values below 0.5 are actually accepted, provided that the resulting $C R$ value is still greater than 0.6 (Fornell \& Larcker, 1981)

\section{Results}

First, Table 1 presents descriptive statistics from respondents. Based on the results of descriptive statistics, it can be seen that the respondents' sex distribution of this study was dominated by female respondents with a percentage of $67.2 \%$ percent, while for male respondents only $32.8 \%$ percent. In addition to gender, based on descriptive statistics it can also be seen that the age of respondents scattered in the age range of 24 to 42 years, shows that employees in this study were mostly included in the age range of Millenials, while 27.2 percent for those under the age of 23 years. Furthermore, for the education of the respondents themselves spread to five levels, namely junior high school or equivalent, high school, D3, D4 / S1, and S2. The results of the descriptive statistics themselves indicate that most employees are at the high school level. Besides high school education, there were also many respondents from the D3 education level. In addition to education, tenure can also be seen that most respondents have a working period of more than 5 years. Descriptive statistics also show how the respondents are spread in the departments in the hospital. Most of the respondents came from the Nursing Department, amounting to $28.5 \%$ of respondents. The results of this descriptive statistic can give an idea of how the demographics of the organization at the place of research were conducted.

Based on the results of the analysis, obtained t-value for the relationship between variables in this study. The T-value considered significant is 1,645 for one-tail. First, the relationship between workplace spirituality variables and employee commitment is significantly positive with a t-value of 5.56 , in addition the relationship between workplace spirituality and turnover intention is significantly negative with a t-value of 
TABLE 1: Respondent's demographics.

\begin{tabular}{|c|c|}
\hline Profile & Category \\
\hline \multirow[t]{2}{*}{ Gender } & Male \\
\hline & Female \\
\hline \multirow[t]{4}{*}{ Age } & Baby boomers generation (55-73) \\
\hline & $X$ generation (43-54) \\
\hline & Millenials generation (24-42) \\
\hline & Z generation ( $\leq 23$ Tahun) \\
\hline \multirow[t]{5}{*}{ Education } & SMP \\
\hline & SMA \\
\hline & D3 \\
\hline & $\mathrm{D} 4 / \mathrm{S} 1$ \\
\hline & $\mathrm{S} 2$ \\
\hline \multirow[t]{4}{*}{ Years of Work } & $<2$ years \\
\hline & $2-3$ years \\
\hline & $3-5$ years \\
\hline & $>5$ years \\
\hline \multirow[t]{9}{*}{ Department } & Administration \\
\hline & Accounting and Finance \\
\hline & Marketing \\
\hline & Maintenance \\
\hline & Midwefery \\
\hline & Nursing \\
\hline & Medical Service \\
\hline & Medical Support \\
\hline & Human Resource \& General Affairs \\
\hline
\end{tabular}

\begin{tabular}{|c|c|}
\hline Total & Percentage (\%) \\
\hline 77 & $32,8 \%$ \\
\hline 158 & $67,2 \%$ \\
\hline 2 & $0,9 \%$ \\
\hline 20 & $8,5 \%$ \\
\hline 149 & $63,4 \%$ \\
\hline 64 & $27,2 \%$ \\
\hline 11 & $4,7 \%$ \\
\hline 115 & $48,9 \%$ \\
\hline 77 & $32,8 \%$ \\
\hline 30 & $12,8 \%$ \\
\hline 2 & $0,9 \%$ \\
\hline 61 & $26 \%$ \\
\hline 35 & $14,8 \%$ \\
\hline 31 & $13,2 \%$ \\
\hline 108 & $46 \%$ \\
\hline 37 & $15,7 \%$ \\
\hline 16 & $6,8 \%$ \\
\hline 2 & $0,9 \%$ \\
\hline 41 & $17,4 \%$ \\
\hline 7 & $3,0 \%$ \\
\hline 67 & $28,5 \%$ \\
\hline 6 & $2,6 \%$ \\
\hline 50 & $21,3 \%$ \\
\hline 9 & $3,8 \%$ \\
\hline
\end{tabular}

-2.26. Second, the relationship between perceived organizational supportand organizational commitment is significantly positive with t-value 4.56 , but the relationship of perceived organizational supportwith turnover intention shows a non-significant and positive relationship with $\mathrm{t}$-value of 1.62 . Then the value of the relationship between organizational commitment and turnover intention is significantly negative with t-value 1.90. These results provide support for $\mathrm{H} 1, \mathrm{H} 2, \mathrm{H} 3$, and $\mathrm{H} 4$ that the hypothesis proposed in this study was accepted. But the insignificant results obtained on $\mathrm{H} 5$ make this hypothesis rejected.

Then, to mediate the effect of organizational commitment, according to (Baron \& Kenny, 2010), three conditions must be met to establish mediation. First, the independent 
variable must be related to the mediator. Second, the mediator must be related to the dependent variable. Third, a significant relationship between the independent variables and the dependent variable will be reduced or no longer significant when controlling the mediator. For H6, the first and second conditions have been fulfilled as explained above. Using the Baron statement, to test the mediation of existing hypotheses, it is seen using direct effect values and indirect effect values. Obtained direct effect -0.34 and indirect effect values of -0.1768 so that the total effect obtained is -0.5168 . Seeing the results of the SEM test conducted, for hypothesis $\mathrm{H} 6$ namely organizational commitment to mediate the relationship between workplace spirituality and turnover intention is acceptable. As for $\mathrm{H} 7$, the first and second conditions have also been fulfilled. However, because $\mathrm{H} 5$ in this study was rejected, then the direct effect value obtained was 0.23 and indirect effects -0.1394 so that the total effect obtained was 0.0906 , then $\mathrm{H} 7$ was also rejected in this study.

\section{Discussion}

There are various unique conditions and findings outside the research hypothesis. Some of the findings presented in the discussion can be the topic of further research to test whether the results obtained will be different. The results obtained in this study cannot prove the influence of perceived organizational supportfor turnover intention and the mediating role of organizational commitment such as the findings of the Filipova (2011). This difference in results is due to the first, the scope of the different research problems, this study modifies the research of Filipova (2011) and Gatling, Kim, \& Milliman (2016) related to the mediation of organizational commitment. Second, it can be caused by different types of organizations. The three differences in the results of this study can be due to the amount of data and measuring instruments that are not the same. Then the latter can be due to the application of organizational support that is not the same in the two organizations. However, after retracing existing research regarding the relationship between perceived organizational supportand turnover intention, there is a study by Shafique et al. (2018) who found a positive relationship between perceived organizational support and turnover intention. Shafique's research was carried out in the textile industry in Pakistan to find out what factors could cause employees to easily leave the company. Based on the results of the study, the reason is that there are many factors that influence employee ratings of organizational support to be bad, including feelings of dissatisfaction, negative behavior of employers towards employees, poor organizational culture, no career opportunities, and poor motivation systems. But back 
to the insignificant relationship obtained, it can be concluded that turnover intention in this study has nothing to do with perceived organizational support. There are other reasons outside the hypothesis that can influence turnover intention in this study.

In addition to not finding the influence between perceived organizational support for turnover intention, this study produces new findings that organizational commitment does not have a mediating effect on the relationship between the two variables. This study found that employee love for work, gender, educational background, and place of residence may influence turnover intention. The findings above need to be proven in further research to be able to find out the truth of these allegations. The results of this study cannot be generalized or cannot be used for various purposes because the topic of the issue raised in this study is a case study in a hospital where other hospitals may have different problems. This study also has several shortcomings that need to be corrected in future studies. The limited number of samples in this study can have an impact on the accuracy of the results of the study so that there is a difference in the significance of the results with other related studies. Future research can use respondents from various hospitals to be able to get more accurate results and the results can be used in general.

\section{Conclusion}

Workplace spirituality has been proven to increase organizational commitment so that hospital management needs to facilitate employees to gather in a forum to solve problems that occur at work. It is evident in this study that one of the most influential factors in workplace spirituality is the positive way used by employees to solve problems. As a form of concern, hospital management needs to maintain its good intentions to continue to help employees. During this time employees feel very helped by working in a hospital. Another positive form of support that can be applied to build positive perceptions is rewards for outstanding employees and fair bonuses. With the better perceived organizational support, it is evident that organizational commitment will also increase. Then to improve the commitment of hospital management employees can add to the spirituality of employee experience and improve the form of organizational support that has been given to employees. Employees are willing to contribute more to the progress of the hospital so that hospital management must also provide a return that can satisfy its employees. The level of turnover intention can be reduced through the application of spirituality in a good workplace. Another strategy that can be applied in establishing a spirituality culture in hospitals is by holding spiritual intelligence 
training for superiors and implementing Corporate Social Responsibility (CSR). But on the other hand, turnover intention cannot be reduced through the perceived organizational support. This can be caused by other factors that might cause turnover intentions such as employees' love of work, gender, educational background, and location of residence. Employee commitment needs to be maintained because it is indirectly able to influence the relationship of spirituality with the desire of employees to resign. To maintain it, hospital management needs to maintain consistency of employee attendance in the study assembly program. Upholding justice, giving motivation by superiors, providing fair rewards, and creating favorable working conditions are strategies that can be applied so that employee commitment is better for reducing turnover rates.

\section{Acknowledgements}

This research was conducted as part of the first author's postgraduate thesis under the supervision of the second author. We gratefully acknowledge the constructive feedback received from the editor and anonymous reviewers.

\section{References}

[1] Altaf, Amal, and Mohammad Atif Awan. "Moderating Affect of Workplace Spirituality on the Relationship of Job Overload and Job Satisfaction." Journal of Business Ethics, vol. 104, no. 1, 2011, pp. 93-99.

[2] Ashmos, Donde P., and Dennis Duchon. "Spirituality at Work: A Conceptualization and Measure." Journal of Management Inquiry, vol. 9, no. 2, 2000, pp. 134-45.

[3] Baron, Beyond, and D. A. Kenny. "Testing Mediation in Nursing Research." Nursing Research, vol. 59, no. 4, 2010, pp. 288-94.

[4] Beehner, C. G., and M. J. Blackwell. "The Impact of Workplace Spirituality on Food Service Worker Turnover Intention." Journal of Management, Spirituality and Religion, vol. 13, no. 4, 2016, pp. 1-20.

[5] Brimeyer, Ted M., et al. "Age, Tenure, Resources for Control, and Organizational Commitment." Social Science Quarterly, vol. 91, no. 2, 2010, pp. 511-30.

[6] Chawla, Vaibhav, and Sridhar Guda. "Individual Spirituality at Work and Its Relationship with Job Satisfaction, Propensity to Leave and Job Commitment: An Exploratory Study among Sales Professionals." Journal of Human Values, vol. 16, no. 2, 2010, pp. 157-67. 
[7] Chiaburu, Dan S., et al. "Social Support in the Workplace and Training Effectiveness: A Longitudinal Analysis." International Journal of Selection and Assessment, vol. 18, no. 2 , 2010, pp. 187-200.

[8] Crook, T. Russell, et al. "Does Human Capital Matter? A Meta-Analysis of the Relationship between Human Capital and Firm Performance." Journal of Applied Psychology, vol. 96, no. 3, 2011, pp. 443-56.

[9] Dessler, Gary. Human Resource Management (13rd Edition). Pearson Education Limited, 2013.

[10] Direnzo, Marco S., and Jeffrey H. Greenhaus. "Job Search and Voluntary Turnover in a Boundaryless World: A Control Theory Perspective." Academy of Management Review, vol. 36, no. 3, 2011, pp. 567-89.

[11] Eisenberger, R. and Huntington, R. "Perceived Organizational Support." Journal of Applied Psychology, 1986.

[12] Filipova, Anna A. "Relationships among Ethical Climates, Perceived Organizational Support, and Intent-to-Leave for Licensed Nurses in Skilled Nursing Facilities." Journal of Applied Gerontology, vol. 20, no. 10, 2011, pp. 1-23.

[13] Fornell, Claes, and David F. Larcker. "Evaluating Structural Equation Models with Unobservable Variables and Measurement Error." Journal of Marketing Research, vol. 18, no. 1, 1981, p. 39.

[14] Gatling, Anthony, et al. "The Relationship between Workplace Spirituality and Hospitality Supervisors' Work Attitudes: A Self- Determination Theory Perspective." International Journal of Contemporary Hospitality Management, vol. 28, no. 3, 2016, pp. 471-489.

[15] Gupta, Manu, et al. "Creating Satisfied Employees through Workplace Spirituality: A Study of the Private Insurance Sector in Punjab (India)." Journal of Business Ethics, vol. 122, no. 1, 2014, pp. 79-88.

[16] Hee, Cordelia H. S., et al. "Strategies for Reducing Employee Turnover and Increasing Retention Rates of Quantity Surveyors Strategies for Reducing Employee Turnover and Increasing Retention Rates of Quantity Surveyors." Construction Management and Economics, vol. 29, no. 10, 2011, pp. 1059-72.

[17] Jena, Lalatendu Kesari, and Sajeet Pradhan. "The Mediating Role of Organisational Citizenship Behavior: A Study of Workplace Spirituality and Employee Retention in Indian Industries." Performance Improvement, vol. 57, no. 6, 2018, pp. 17-35.

[18] Jones, Gareth R. Socialization Tactics, Self-Efficacy, and Newcomers' Adjustments to Organizations. Vol. 29, no. 2, 1986, pp. 262-79. 
[19] Kazemipour, Farahnaz, and Salmiah Mohd Amin. "The Impact of Workplace Spirituality Dimensions on Organisational Citizenship Behaviour among Nurses with the Mediating Effect of Affective Organisational Commitment." Journal of Nursing Management, vol. 20, no. 8, 2012, pp. 1039-48.

[20] Kehoe, Rebecca R., and Patrick M. Wright. "The Impact of High Performance HR Practices on Employees' Attitudes and Behaviors." Journal of Management, vol. 39, no. 2, 2013, pp. 366-91.

[21] King, Megan F., et al. "The Concept, Dimensions and Methods of Assessment of Human Well-Being within a Socioecological Context: A Literature Review." Social Indicators Research, vol. 116, no. 3, 2014, pp. 681-98.

[22] Kinicki, Angelo, and Mel Fugate. Organizational Behavior: A Practical, ProblemSolving Approach. McGraw-Hill Education, 2016.

[23] Kirsten, Wolf. "3 Making the Link between Health and Productivity at the Workplace - A Global Perspective." Industrial Health, vol. 48, no. 3, 2010, pp. 251-55.

[24] Kovner, Christine T., et al. "Estimating and Preventing Hospital Internal Turnover of Newly Licensed Nurses: A Panel Survey." International Journal of Nursing Studies, vol. 60, Elsevier Ltd, 2016, pp. 251-62.

[25] Kreitner, Robert, and Angelo Kinicki. Organizational Behavior (9th Edition). McGrawHill International Edition, 2010.

[26] Kurtessis, James N., et al. "Perceived Organizational Support: A Meta-Analytic Evaluation of Organizational Support Theory." Journal of Management, vol. 43, no. 6, 2017, pp. 1854-84.

[27] Lee, Seonjeong, et al. "Serving with Spirit: An Integrative Model of Workplace Spirituality within Service Organizations." Journal of Management, Spirituality and Religion, vol. 11, no. 1, 2014, pp. 45-64.

[28] Mowday, Richard T., et al. "The Measurement of Organizational Commitment." Journal of Vocational Behavior, 1979, doi:10.1016/0001-8791(79)90072-1.

[29] Pallas, Linda O’Brien, et al. “Impact and Determinants of Nurse Turnover: A PanCanadian Study." Journal of Nursing Management, vol. 18, no. 8, 2010, pp. 1073-86.

[30] Petchsawang, Pawinee, and Dennis Duchon. "Spirituality \& Workplace Spirituality, Meditation, and Work Performance." Journal of Management, Spirituality \& Religion, vol. 9, no. 2, 2012, pp. 189-208.

[31] Shafique, Muhammad Zubair, et al. "The Effects of Perceived Organizational Support on the Turnover Intention: A Case Study of Textile Sector." International Journal of Academic Research in Business and Social Sciences, vol. 8, no. 9, 2018, pp. 547-58. 
[32] Takase, Miyuki. "A Concept Analysis of Turnover Intention: Implications for Nursing Management." Collegian, vol. 17, no. 1, Royal College of Nursing Australia, 2010, pp. 3-12.

[33] Vandenberghe, Christian. "Workplace Spirituality and Organizational Commitment: An Integrative Model." Journal of Management, Spirituality \& Religion, vol. 8, no. 3, 2011, pp. 211-32.

[34] Vnoučková, Lucie, et al. "Approaches to the Talent Management Agenda in Forestry Companies." Central European Forestry Journal, vol. 62, no. 1, 2016, pp. 29-38.

[35] Wong, Anthony, and Canon Tong. "Evaluation of Organizational Commitment Models and Their Components in Asian Cities." International Journal of Human Resource Studies, vol. 4, 2014, pp. 66-96. 